\title{
The Influence of E-government Practices on good governance from the perspective of Public in Lebanon
}

\author{
Hassan Alaaraj (Corresponding Author) \\ School of Economics, Finance and Banking, University Utara Malaysia \\ 06010 UUM Sintok, Kedah Darul Aman, Malaysia \\ E-mail: araj.hassan@hotmail.com \\ Professor, Dr. Fatimah Wati Ibrahim \\ School of Economics, Finance and Banking, University Utara Malaysia \\ 06010 UUM Sintok, Kedah Darul Aman, Malaysia \\ E-mail: fatimah@uum.edu.my
}

Accepted: July 25, 2014

Doi:10.5296/ jpag.v4i3.6405 URL: http://dx.doi.org/10.5296/ jpag.v4i3.6405

\begin{abstract}
The objective of this study was to examine empirically the influence of e-government practices on good governance from the perspectives of public in Lebanon. This paper presents a theoretical research framework to determine the relationships between the proposed variables supported by literature review from previous studies. Questionnaires were distributed among managers and employees from 600 SMEs in Beirut and the usable response rate was $94 \%$. To test the relationships, four hypotheses were developed in which two were accepted and two were rejected upon data analysis using SPSS and AMOS. The main research outcomes indicate that in general, e-government practices have a positive and significant influence on good governance. Particularly, good governance is positively and significantly influenced by e-service but not by e-administration and e-procurement. Finally, limitations of the study were discussed for recommending future studies especially at the empirical level.
\end{abstract}

Keywords: E-government, Good governance, Public, Lebanon 


\section{Introduction}

Good governance acts as a strong foundation for the organizational reform especially through the cultural, intellectual and technological interactions among the employees. The principles of good governance drive the employees to be more effective and transparent in providing a high quality of services. In addition, it protects them from being involved in corruption behaviors. According to Alemayehu (2008), the quality of government services can be improved and more personalized through the use of information communication technology (ICT). Consequently, governments rely on technological approaches where it plays a core role in creating additional value to the good governance in the long-run trend.

Most of developing countries, such as Lebanon are adopting e-government as an innovative strategy in its economic reform since it can add value to the economic efficiency and provide transparent environment to both government and public as well (Al-azar, 2012).Furthermore, the implementation of e-government is supposed to reduce the cost of service delivery in the governmental organizations, provide more efficient administration, promote transparency and enhance the efficiency of government procurements (REO, 2012; Berthon et al., 2008).

Therefore, this paper aims to determine the influence of e-government practices including e-services, e-administration and e-procurement on good governance from the perspectives of public in Lebanon. This is because the public can evaluate such relationships in a more objective manner especially that they are regularly interacting with government services as an external party.

\section{State of E-government and Good Governance in Lebanon}

It is declared by several reports such as IIF (2005) that Lebanon's government sector is overwhelmed with corruption that makes the general business environment not attractive to local and international investment. Although good governance restructures the role of the government and facilitates different economic activities however, Lebanon is still facing several challenges that prevent it from achieving the state of good governance and full economic potential as well.

Marcel (2013) considered that the critical weakness in the Lebanese governance system is rather in the risk of corruption where strengthening processes of accountability, improving the discovery of information and building capacity in auditing can improve this risk.

Table 1.The Lebanese Corruption Perception Index

\begin{tabular}{|l|l|l|l|l|}
\hline Year & $\mathbf{2 0 0 9}$ & $\mathbf{2 0 1 0}$ & $\mathbf{2 0 1 1}$ & $\mathbf{2 0 1 2}$ \\
\hline Corruption perception index (CPI) & 2.5 & 2.5 & 2.5 & 3 \\
\hline Rank of corruption perception index & 130 & 127 & 134 & 128 \\
\hline
\end{tabular}

As shown in Table 1, the rank of Lebanon was 128 among 176 countries with respect to corruption perception index (Bank Med, 2013; CPI, 2012; The Daily Star, 2011). This 
indicates lack of the transparency within government organizations and the high level of corruption where zero is the index for most corrupt and 10 is least corrupt (TI, 2010).

However, some indications for improvement can be noticed within the Lebanese government sector in terms of good governance where many efforts have been made toward significant reforms that would increase the competitiveness of government sector and make it more attractive to investors (Kefela, 2011; IIF, 2005). For instance, the Lebanese Ministry of Finance has implemented reforms to enhance transparency and fight corruption through calling taxpayers for paying through banks (US Commercial Services, 2012).

One of the main economic reforms that is being developed by the Lebanese government is the implementation of e-government practices within the public sector. The introduction of e-government systems in Lebanon is considered as a significant tool for the administrative improvement (Saidi, 2003). E-government is being implemented to achieve efficient governance that would fight corruption in developing countries (Pathak \& Prasad, 2005). Lebanon comes in the 84th position among 135 countries and the 93rd amongst 144 countries regarding the technological readiness (Weforum, 2013). Yet the public administration and governance situation is suffering from various aspects which inhibit public administration and governance in achieving the e-readiness strategies appropriately (Dawlati, 2013).

It was reported that the government's transparency of policymaking in Lebanon is listed the $104^{\text {th }}$ amongst 135 countries in the world (The Heritage Foundation, 2013). In addition to this lack of transparency, the aspects of good governance in Lebanon such as efficiency, effectiveness and accountability are not conducted properly because of insufficient and unqualified employees in the government organizations, offices equipment are outdated, Inadequate compensation system and over centralized procedures ( Dawlati, 2013).

Currently, there is shortage of studies in Lebanon related to the implementation of e-government and its influence on good governance in the public sector. Few studies were conducted (Choueiri et al., 2013; Al-azar, 2012; Fawaz, 2004) but there is no empirical research to be relied on. Therefore, this research has significant value for public organizations. First, it focuses on the e-government features that government must practice to properly implement and maintain its reforms. Second, it tends to encourage organizations to adopt ICT tools in their strategies to eliminate corruption and enhance the good governance within its organizations.

\section{Literature Review}

Due to the lack of transparency and efficiency in most of developing countries governments, public sectors have started to adopt corporate governance principles, thus initiating so-called public sector governance (Kluvers \& Tippett; 2010; ANAO, 2003). From the perspective of decision making, UNESCAP (2012) defined governance as how to make the decision and by which decision the process is implemented. These processes generate results that match with the needs of the community through the efficient use of the resources. Jusoh et al. (2009) also defined good governance as a transformative process of breaking previous conditions, while the World Bank (1989) reported previously that "governance is a means by which to control 
corruption and consequently is imperative for economic development and poverty reduction in these countries".

Therefore, good governance is related to the contribution of public administration through the development of strategies and procedures by which organizations are regulated, directed and held to account (Khan; 2013). Lot off studies have listed the main features of good governance namely accountability, transparency, high standard of professional ethics, openness, responsiveness, inclusiveness, participation, consensus and orientation (UNESCAP; 2012; Pillay, 2004). These principles and behavioral governance practices have potentials to fight corruption and enhance the public sector to deliver efficient, transparent and high quality services.

It is proposed by several studies (Gianluca, 2011; Park \& Blenkinsopp, 2011; Ruhanen et al., 2010) that the dimensions of transparency, efficiency and accountability are important determinants to promote good quality of services. This was illustrated by Ruhanen et al. (2010) who synthesized 53 different articles related to good governance and found that these dimensions are the most frequently studied throughout the literature. Efficiency is the result of governance activities that meet the needs of society through the proper use of resources (Sentosa, 2009). Gianluca et al. (2011) also defined efficiency as the degree to which organizations are able to transform the optimal use of input to the acceptable level of output by avoiding waste and ensuring customer's satisfaction through service delivery.

Salim and Abidin (2011) argued that the principle of transparency is noted as more significance and widespread in the public and private governance. Accordingly, transparency is defined as "the open flow of information" that is directly available, accessible, free and understandable to those who will be in the charge of making decision (UNESCAP, 2012; Park \& Blenkinsopp, 2011). Moreover, accountability is defined as a consequence of transparency, in which it advances a better quality of good governance (Egwuonwu, 2011). It makes organizations and individuals answerable and responsible to the decision that has been taken and aware of the performance consequences (Sentosa, 2009; Wong \& Welch, 2004).

As for e-government, it is the interaction between government and different parties such as citizens, businesses, employees and even other governments or agencies through the use of digital services (Jeong, 2007). Governments lean to engage with e-government implementation more and more in order to improve the public services towards good governance. This stems from the belief that e-government is a great potential to achieve a lot on the way to successful development (Musa, 2010). It is argued that implementing e-government practices such as e-service, e-administration and e-procurement can break down bureaucratic barriers which restrict corruption and improve the productivity in the nation (Bwalya, 2012; Tehrani, 2007).

Ndou (2004) defined e-service as connecting the relationship between citizens and government through automating the services while Rotchanakitumnuai (2013) claimed that e-procurement is employing online information technology to purchase services and goods for public sectors. Moreover, e-administration is mainly based on various types of management work, internal routines, computerizing the administrative jobs and realizing of 
strategic connections among different departments (Khan, 2013; Ndou, 2004).

Conceptually, several studies (Haque \& Pathrannarakul, 2013; Rana et al., 2011; Kettani et al., 2008; Tolbert \& Mossberger, 2006; IOS Press, 2005; Mucavele, 2003; ADB, 2001) stated that e-government is a tool developed by the governments to achieve the principles of good and transparent governance such as accountability, responsiveness, efficiency, effectiveness, openness, commitment and transparency. It offers prospective solutions across the whole sectors of government, where leaders are facing governance and administrative problems.

Despite such observations, other researchers have observed the limited effect of e-government on good governance application. Holliday and Yep (2005) analyzed China's progress towards e-government and its effects on governance and service delivery. They found that China's progress towards e-government has remained superficial despite of the contemporary changes occurring in the official positions towards reforms and the implementation of various e-initiatives since the early 1990s. The authors also argued that e-government in China is recently having a limited impact on governance due to several factors that hinder the effective development of e-government in the country.

In relation to this issue, West (2004) assessed the impact of e-government on each of service delivery, public attitude, trust and democratic responsiveness. The research was based on both website content and public opinions. The findings showed that e-government practices in the USA has deficient in its ability to renovate service delivery and enhance the public trust in government although of its potential to make actions different over the long term.

Therefore, this paper aims to fill in the gaps of literature and highlight the state of e-government and good governance in Lebanon and particularly determine the influence of e-government practices including e-service, e-administration and e-procurement on good governance from the perspective of public in Lebanon.

\section{Research Framework}

The previous literature indicated how e-government practices encourage public organizations to govern more efficiently, transparently and effectively. Thus, the ease of utilizing ICT and the smooth diffusion of such innovation strategies would increase the capabilities of governments to perform in a good governance manner. This research is based on the diffusion of innovation theory (DOI). It is a popular theory that was used in most of ICT researches to explain user's adoption of new innovations and technologies (Sang et al., 2009; Lean et al., 2009; Carter \& Bélanger, 2005; Rogers, 1995).

DOI theory suggests that innovation diffusion is based on the perception of the characteristics of the technology and the user's perception of the system. However, the rate of diffusion is affected by an innovation's relative advantage, complexity, compatibility and trial ability (Al-zuabi, 2012; Carter \& Bélanger, 2005).

The previous literature emphasized on the concept that e-government is a tool to achieve good and transparent governance while offering potential solutions to leaders across the whole sectors of government (Haque \& Pathrannarakul, 2013; Rotchanakitumnuai, 2013; 


\section{Macrothink}

Journal of Public Administration and Governance ISSN 2161-7104 2014, Vol. 4, No. 3

Mucavele, 2003). Also, it is argued that ICT can offer potentially useful tools to governments and help them to restore public trust by enhancing transparency, cost efficiency, effectiveness and policy participation (Moon, 2003).

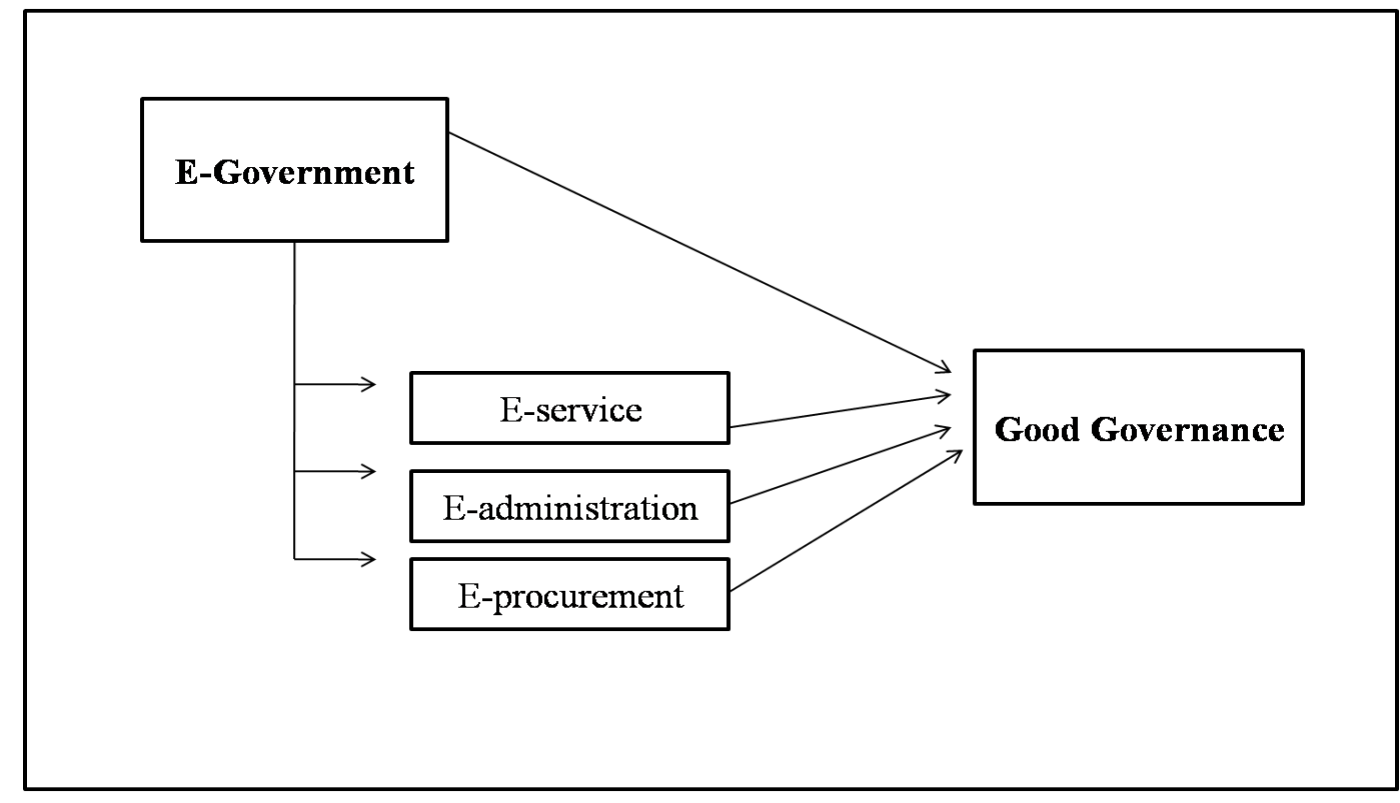

Figure 1. The Theoretical Research Framework

Based on this theoretical and empirical background, the research theoretical framework is developed as shown in Figure 1 and four hypotheses are proposed to study the influence of e-government practices on good governance in Lebanon.

H1: E-government has a significant and positive influence on good governance.

H2: E- service has a significant and positive influence on good governance.

H3: E- procurement has a significant and positive influence on good governance.

H4: E-administration has a significant and positive influence on good governance.

\section{Methodology and Data Collection}

The methodology applied for this research is quantitative, where 600 SMEs in Beirut, Lebanon were surveyed. The sample was chosen since managers and employees of SMEs are educated respondents who use ICT and interact with online government services by virtue of their working conditions. Therefore, 400 self-administered questionnaires were distributed among employees and managers in SMEs and the usable response rate was 94\%.

The questionnaire was composed of 50 items derived from valid and reliable previous studies (Dawlati, 2013; Rotchanakitumnuai, 2013; Jalali \& Khorasani, 2012; Grimmelikhuijsen, 2012; Esri, 2012; Al-zoubi, et al., 2011; Park \& Blenkinsopp, 2011). Respondents were asked 


\section{Macrothink}

to rate their level of agreement from strongly disagree to strongly agree based on six point Likert scales.

The collected data was analyzed using Statistical Package for Social Science (SPSS 19) and structural equation modeling (SEM) through AMOS 16 software. The results obtained showed that males represented the majority of respondents with $60 \%$ while $40 \%$ were females. Most of respondents (49.3\%) were between 41 and 50 years old and $49.6 \%$ of the respondents have a master degree. Moreover, $45.1 \%$ of respondents had very good ICT skills and $43.7 \%$ of respondents use ICT very frequently.

Table 2. Reliability Test Results

\begin{tabular}{|c|c|c|c|c|c|}
\hline Variable & \multicolumn{4}{|c|}{ Number of items } & $\alpha$ \\
\hline \multirow{3}{*}{ E-government } & \multirow{3}{*}{24} & ES & 8 & 0.88 & \multirow{3}{*}{0.93} \\
\hline & & EA & 9 & 0.83 & \\
\hline & & EP & 7 & 0.90 & \\
\hline Good Governance & \multicolumn{4}{|l|}{26} & 0.91 \\
\hline
\end{tabular}

Measuring the value of Cronbach's Alpha coefficient $(\alpha)$ illustrated that all variables had a good level of internal consistency as shown in Table 2. The values ranged between 0.77 and 0.93 which are above the 0.7 threshold suggested by Hair et al. (2010) and Shook et al. (2004).

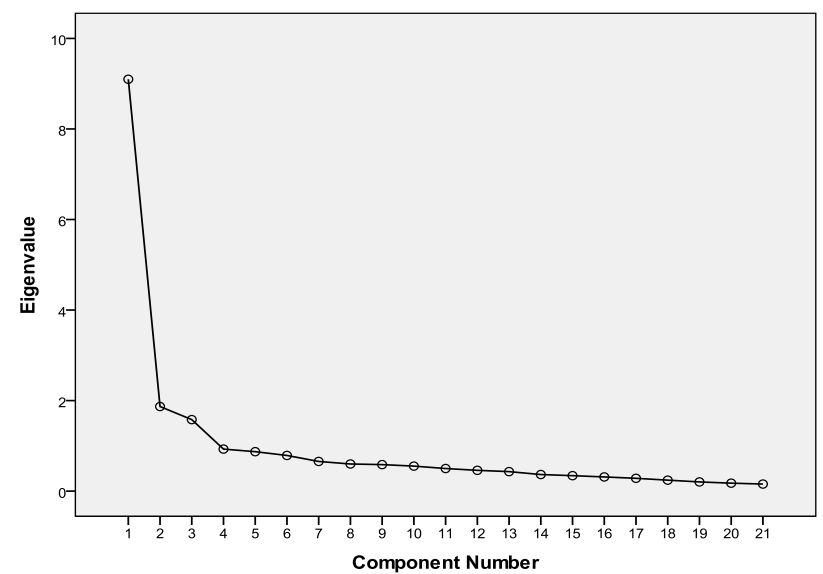

Figure 1.Screen Plot of E-government

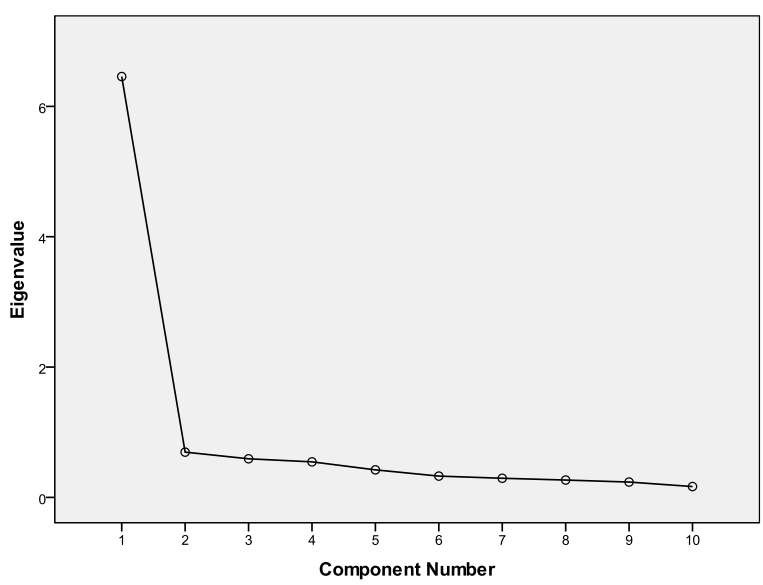

Figure 2.Screen Plot of Good Governance 


\section{Macrothink}

Journal of Public Administration and Governance

ISSN 2161-7104

2014, Vol. 4, No. 3

Explanatory factor analysis (EFA) was used to measure the validity of variables and the results obtained confirm this validity as shown in Figure 2 and Figure 3. The items of e-government loaded on three main components ES, EA and EP with Kaiser-Meyer-Olkin value $\mathrm{KMO}=0.92$, which is above the 0.5 threshold suggested by Hair et al. (2010). Items of good governance loaded only on one component as it is the dependent variable with KMO = 0.88 .

\section{The Causal Relationship between E-government Practices and Good Governance}

In order to obtain the first and second order structural models which are presented in Figure 4 and Figure 5 respectively, the confirmatory factor analysis (CFA) and goodness of fit were measured using SEM. The structural models had goodness of fit indices above the threshold as suggested in Table 3.

Table 3.Recommendation Values of Goodness-of-Fit Indicators

\begin{tabular}{|l|l|}
\hline Measures & Threshold Values \\
\hline RMSEA & $<0.08$ \\
\hline GFI & $\geq 0.90$ \\
\hline AGFI & $\geq 0.90$ \\
\hline CFI & $\geq 0.90$ \\
\hline TLI & $\geq 0.90$ \\
\hline
\end{tabular}

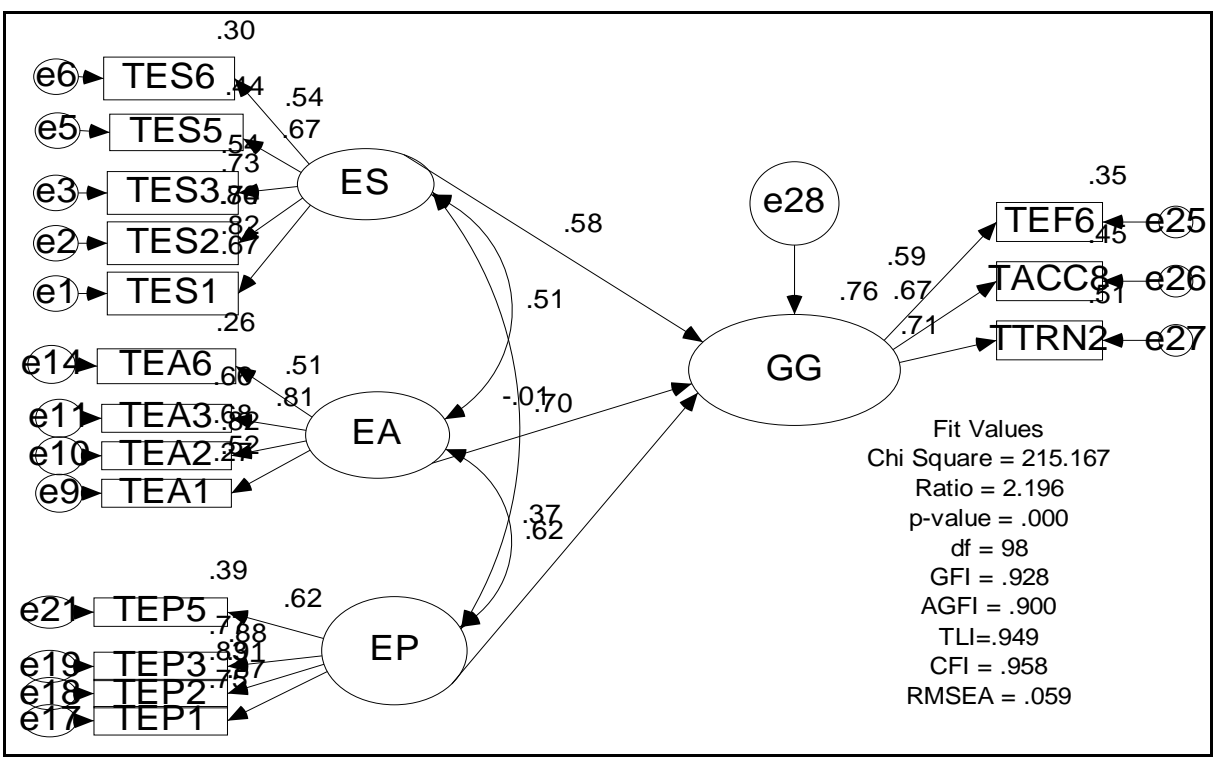

Figure 4. First Order structural Model for ES, EA and EP with GG 


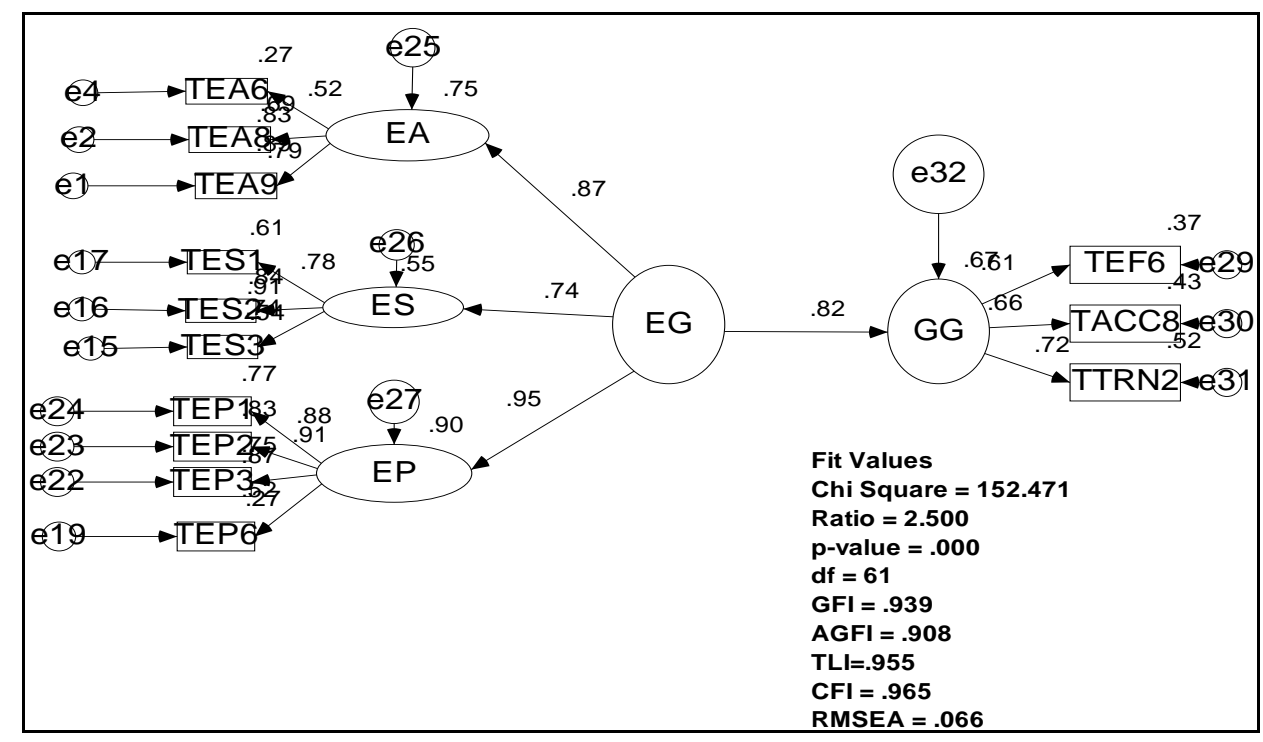

Figure 5. Second Order Structural Model for E-Government and Good Governance

The causal relationships between e-government practices and good governance are illustrated in Table 4. Based on the second order structural model, e-government has a positive and significant influence on good governance at 0.001 level $(\beta=0.817)$ supporting the first hypothesis. But the outcomes obtained from the first order structural model showed variety of results. The second hypothesis was supported where e-service has a positive and significant influence on good governance at 0.001 level $(\beta=0.578)$. However, the third hypothesis was rejected where e-administration has an insignificant influence on good governance $(\beta=-$ 0.007, P-value $=0.922$ ). On the other hand, e-procurement showed a significant relationship with good governance at 0.001 level, but it performed a weak influence with $\beta=0.369<0.5$ as suggested by Hair et al. (2006). Therefore, the fourth hypothesis is not well supported.

Table 4.Standardized Regression Weights: (Group number 1 - Default model)

\begin{tabular}{|l|l|l|l|l|}
\hline IV & & DV & $\begin{array}{l}\text { Estimate } \\
(\beta)\end{array}$ & $\mathrm{P}$ \\
\hline E-Government & $\rightarrow$ & Good Governance & 0.817 & $* * *$ \\
\hline E- Service & $\rightarrow$ & Good Governance & 0.578 & $* * *$ \\
\hline E- Administration & $\rightarrow$ & Good Governance & -0.007 & 0.922 \\
\hline E-Procurement & $\rightarrow$ & Good Governance & 0.369 & $* * *$ \\
\hline
\end{tabular}

$* * *$ Significant at $\mathrm{P}$-value $=0.001$ 


\section{Discussion}

The research findings are consistent with the findings of the previous studies (Rotchanakitumnuai, 2013; Haque \& Pathrannarakul, 2013; Navarro et al., 2012; Raghupathi \& Wu, 2011; Salin \& Abidin, 2011; Rana et al., 2011) where the majority of studies stated that e-government is a tool developed by the governments to achieve the principles of good and transparent governance such as accountability, responsiveness, efficiency, effectiveness, openness, commitment and transparency. In addition, Siddiquee (2008) argued that e-government can improve transparency and reduce corruption in the public sector. However, this general direct relationship does not reflect whether all e-government practices influence good governance significantly. Thus, it was essential to examine individually the direct influence of e-service, e-administration and e-procurement on good governance.

For instance, the results of e-service are in line with the findings of Salam and Islam (2013) who stated that e-services are positively related with effective governance and that good governance has the potential to improve service delivery and customer satisfaction. Thus, it minimizes corruption, provides efficient service, ensures accountability and intensifies the transparency through the accessibility and greater convenience of interaction. Pathak and Prasad (2005) also claimed that the availability of quality information of services online enhances transparency, where most studies showed that transparency have increased by making the information about the functioning of government and its officials available to the citizens permanently or on demand.

On the other hand, Kettani et al. (2008) also stated that most e-government systems that are currently deployed in developing countries fail to enhance good governance for a number of reasons such as socio-political and economical factors besides the low levels of acceptability, usability, accessibility and appropriateness of e-government systems deployed for citizens.

\section{Conclusion}

In conclusion, this study has empirically determined the influence of e-government practices on good governance in Lebanon. It has contributed theoretically and empirically by highlighting the case study of Lebanon as one of the developing countries that are struggling to implement e-government strategies in their economic reform. It has also showed how e-government programs brought governance closer to the public by making government accurately transparent and accountable to the public. The limitation of this study is related to the sample which is restricted to managers and employees of SMEs in Beirut. Thus, future studies can be expended geographically. In addition, different methodology can be conducted in order to have variety of respondents and obtain more generalizable research outcomes.

\section{Acknowledgement}

The research was conducted under the supervision of Professor, Dr. Fatimah Wati Ibrahim and the support of School of Economic, Finance, and Banking and College of Business at University Utara Malaysia. 


\section{References}

ADB. (2001). Toward e-development in Asia and the pacific: A strategic approach for information and communication technology. Asian Development Bank: Strategy and Policy $\begin{array}{lllll}\text { Department. } & \text { Retrieved } & \text { September } & 2013 \text { from }\end{array}$ http://www.adb.org/sectors/ict/policies-and-strategies

AL-azar (2012). AUB-led workshop: E-government paves the way for better relations between citizens and the state. American University of Beirut: E-government stakeholders' engagement workshop. Retrieved from http://www.aub.edu.lb/communications/media/Documents/april-2012/e-government-EN.pdf

Al-zoubi, M., et al. (2011). Analysis of e-government adoption and organization performance in the Jordan businesses sector. Academic Research International, 1(3).

Alzubi, M. (2012). Electronic government adoption model among business organizations in Jordan. Published thesis, University Utara Malaysia.

ANAO. (2003). Better practice public sector governance. National institute for governance, Australian National Audit Office. Retrieved from http://anao.gov.au/ /media/Uploads/Documents/better_practice_public_sector_governance1.p df

Bank Med. (2013). Lebanon economic outlook: market \& economic research. Retrieved July 18,2013,from

http://www.bankmed.com.lb/SiteCollectionDocuments/aLebanon\%20Economic\%20Outlook\%20January\%202013.pdf

Bwalya, K., et al. (2012). E-government and technological utopianism: exploring Zambia's challenges and opportunities. Electronic Journal of e-Government, 10(1), 16-30.

Carter, L., \& Belanger, F. (2005). The utilization of e-government services: Citizen trust, innovation and acceptance factors. Information Systems Journal, 15(1), 5-25.

Choueiri, E., et al. (2013). An overview of e- government strategy in Lebanon. International Arab Journal of E-Technology, 3(1).

CPI. (2012). Transparency International Corruption Perceptions Index 2012. Transparency International: the global coalition against corruption. Ernst \& Young. Available at: http://www.ey.com/Publication/vwLUAssets/2012_TI_CPI/\$FILE/2012\%20TI\%20CPI.pdf

Dawlati. (2013). E- services. The official website of Lebanese e-government portal, Lebanese republic. Retrieved November 22, 2013 from http://www.dawlati.gov.lb/en/eservices

Egwuonwu, R. (2011). Behavioral governance, accounting and corporate governance quality. Journal of Economics and International Finance. 3(1), 1-12.

Esri. (2012). Transparency and accountability for state and local governments. New York: $\begin{array}{lllll}\text { Esri. Retrived } & \text { December } & 274 & \text { from }\end{array}$ http://www.esri.com/library/brochures/pdfs/transparency-and-accountability 


\section{I Macrothink}

Journal of Public Administration and Governance ISSN 2161-7104 2014, Vol. 4, No. 3

Fawaz, J. (2004). The Lebanese IT sector and professional computer association. WITSA General Assembly meeting in Athens. Retrieved October 17, 2013 from http://www.witsa.org/v2/resources/presentations/Archive/TheLebaneseITSector_andProfessio nalComputerAssociation.pdf

Gianluca, M., et al. (2011). A multi-level framework for ICT-enabled governance: assessing the non-technical dimensions of 'government openness, Electronic Journal of e- Government, $9(2), 152-165$.

Grimmelikhuijsen, S. (2012). Transparency and trust: An experimental study of online disclosure and trust in government. Published thesis at Utrecht University: Mascot. Retrieved November 29, 2013 from http://dspace.library.uu.nl/handle/1874/218113.

Hair, J., et al. (2010). Multivariate data analysis: a global analysis. New Jersey: Pearson

Hair, J. F., et al. (2006). Multivariate Data Analysis: New Jersey: Prentice-Hall, Upper Saddle River.

Haque, P., \& Pathrannarakul, P. (2013). E-government towards good governance: A global appraisal. Journal of E-Governance, 36(1), 25-34.

Holliday, I., \& Yep, R. (2005). E-government in China. Public Administration and Development, 25(3), 239-249.

IIF. (2005). Corporate governance in Lebanon: an investor perspective. IIF Equity Advisory Group, the Institute of International Finance, Inc. Available at http://www.iif.com/download.php?id=2H3vbkSCDvU=

IOS Press. (2005). The role of e-government in Europe's future. The Journal of E-Government Policy and Regulation, 28(1), 59-68.

Jalali, F., \& Khorasani, F. (2012). The relationship between e-government and the public trust among the citizens in district 5, Tehran. Research Journal of Applied Sciences, Engineering and Technology, 4(23), 5261-5267.

Jeong, C. (2007). Fundamental of Development Administration. Selangor: Scholar Press. ISBN 978-967-5-04508-0

Jusoh, H., et al. (2009). The role of efficient urban governance in managing Kuala Lumpur city-region development. Asian Social Science, 5(8), 1-19.

Kefela, G. (2011). Good governance enhance the efficiency and effectiveness public spending-Sub Saharan countries. African Journal of Business Management, 5(11), 3995-3999.

Kettani, D., et al. (2008). Proposition of a method for the development and deployment of e-government systems that emphasize good governance. Proceeding of International MCETECH Conference on e-Technologies, IEEE. DOI 10.1109. 


\section{Macrothink}

Journal of Public Administration and Governance ISSN 2161-7104 2014, Vol. 4, No. 3

Khan, M. (2013). E-government, GIS and good governance. Public management, 95(1), $18-23$.

Kluvers, R. (2010). Mechanisms of accountability in local government: an exploratory study. International Journal of Business and Management, 5(7), 1-8.

Lean, O., et al. (2009). Factors influencing intention to use e-government services among citizens in Malaysia. International Journal of Information Management. 29(6), 458-475.

Marcel, V. (2013). Lebanon: What are the governance prospects for the petroleum sector? Middle East Strategic Perspectives, a Strategic Outlook on Middle Eastern Affairs. $\begin{array}{llll}\text { Retrieved } & \text { November } & 20, & 2013\end{array}$ http://www.mestrategicperspectives.com/2013/05/03/what-are-the-governance-prospects-for-1 ebanons-petroleum-sector/

Moon, M. (2003). Can it help government to restore public trust? Declining public trust and potential prospects of it in the public sector. In Proceedings of the $36^{\text {th }}$ Hawaii International Conference on System Sciences (HICSS'03), IEEE. Retrieved from http://ieeexplore.ieee.org/xpls/abs_all.jsp?arnumber=1174303\&tag=1

Mucavele, F. (2003). Improving the investment climate through e-government and e-land registry in Mozambique. In Proceeding of global forum on international investment; OECD: Johannesburg. Available at: http://www.oecd.org/daf/inv/investmentstatisticsandanalysis/21002025.pdf

Musa, M. (2010). An e-readiness assessment tool for local authorities: a pilot application to Iraq. Published thesis at the American University in Cairo. Retrieved from http://dar.aucegypt.edu/bitstream/handle/10526/713/2010ppadmohammedmusa.pdf?sequence $=1$

Navarro, J., et al. (2012). E-government and citizen's engagement with local affairs through e-websites: The case of Spanish municipalities. International Journal of Information Management, 32, 469-478.

Ndou, V. (2004). E-government for developing countries: opportunities and challenges. The Electronic Journal on Information Systems in Developing Countries, 18(1), 1-24.

Park, H., \& Blenkinsopp, J. (2011). The roles of transparency and trust in the relationship between corruption and citizen satisfaction. International Review of Administrative Sciences, 77(2), 254-274.

Pathak, R., \& Prasad, R. (2005). Role of e-governance in tackling corruption and achieving societal harmony: Indian experience. Proceeding of the annual conference 200; Network of Asia-pacific schools and institutes of public administration and governance (NAPSIPAG), Beijing, PRC, 5-7 December. from http://www.napsipag.org/pdf/tackling_corruption.pdf 


\section{Macrothink}

Journal of Public Administration and Governance ISSN 2161-7104 2014, Vol. 4, No. 3

Pillay, S. (2004). Corruption: the challenge to good governance; a South African perspective. The International Journal of Public Sector Management, 17(7), 586-605.

Raghupathi, W., \& Wu, S. (2011). The relationship between information and communication technologies and country governance: an exploratory study. Communication of the association for information systems, 28(12), 181-198.

Rana, N., et al. (2011). Reflecting on e-government research: Toward taxonomy of theories and theoretical constructs. International Journal of Electronic Government Research, 7(4), 64-88.

Rogers, E. M. (1995). Diffusion of Innovation. New York: Free Press.

Rotchanakitumnuai, S. (2013). The governance evidence of e-government procurement. Transforming Government: People, Process and Policy, 7(3), 309-321.

Ruhanen, et al. (2010). Governance: a review and synthesis of the literature. Tourism review, 65(4), 4-16.

Saidi, N. (2003). Mobilizing the Arab private sector for corporate governance. Centre for International Private Enterprise. Retrieved July 11, 2013 from http://www.cipe.org/publications/detail/mobilizing-arab-private-sector-corporate-governance

Salam, M., \& Islam M. (2013). E-government service delivery: an assessment of district e-service centres in bangladesh. JU Journal of Information Technology (JIT), 2.

Salin, A., \& Abidin, Z. (2011). Being transparent: an evidence of a local authority in Malaysia. In Proceeding of International Conference on Sociality and Economics Development, 10, Singapore: Press. Retrieved from http://www.ipedr.com/vol10/68-S10002.pdf

Sang, S., et al. (2009). E-Government Adoption in ASEAN: the Case of Cambodia. Internet Research, 19(5), 517-534.

Sentosa, I. (2009). The Mediating effect of good governance on the relationship between managerial roles and personal development in West Sumatera Provincial government-Indonesia. Published PhD thesis at Universiti Utara Malaysia.

Siddiquee, N. (2008). Service delivery innovations and governance: the Malaysian experience. Transforming Government People, Process and Policy, 2(3), 194-213.

Smith, M. (2010). Building institutional trust through e-government trustworthiness cues. Information Technology \& People. 23(3), 222-246.

Tehrani, M. (2007). Some Steps towards implementing e-government. SIGCAS Computers and Society, 37(1).

The Daily Star. (2011). Lebanon ranks $13^{\text {th }}$ in MENA on Corruption Perception Index. Retrieved November 20, from http://www.dailystar.com.lb/Business/Lebanon/2011/Dec-02/155793-lebanon-ranks-13th-inmena-on-corruption-perception-index.ashx\#axzz21C7MW8Cy 


\section{Macrothink}

Journal of Public Administration and Governance ISSN 2161-7104 2014, Vol. 4, No. 3

The Heritage Foundation. (2013). The 2013 Index of Economic Freedom of Lebanon, 285-286. Retrieved October 7, 2013 from http://www.heritage.org/index/country/lebanon

TI. (2010). The good governance challenge: Egypt, Lebanon, Morocco and Palestine. Transparency International: USAID. ISBN: 978-3-935711-50-0

Tolbert, C., \& Mossberg, K. (2006). The effects of e-government on trust and confidence in government. Public Administration Review, 66(3), 302-478.

UNESCAP. (2012). What is good governance? United Nations Economic and Social Commission for Asia and the Pacific. Retrieved October 3, 2013 from www.uniscap.org/huest/gg/governance.htm

US Commercial Services. (2012). Doing business in Lebanon in 2012. Country commercial guide for U.S companies. Retrieved October 20, 2013 from http://photos.state.gov/libraries/lebanaon/231771/PDFs/Country\%20Commercial\%20Guide\% 20Lebanon\%202012.pdf

Weforum. (2013). Global risks. ( $8^{\text {th }}$ Ed.). Switzerland: World Economic Forum. Retrieved from www3.weforum.org/docs/WEF_GlobalRisks_Report_2013.pdf

West, D. (2004). E-government and the transformation of service delivery and citizen attitudes. Public administration review, 64(1), 15-27.

World Bank (1989), Sub-Saharan Africa: From Crisis to Sustainable Growth, World Bank, Washington

Wong, W., \& Welch, E. (2004). Does e-government promote accountability? A comparative analysis of website openness, government accountability, and Governance. International Journal of Policy, Administration, and Institutions, 17(2), 275-297.

\section{Copyright Disclaimer}

Copyright reserved by the author(s).

This article is an open-access article distributed under the terms and conditions of the Creative Commons Attribution license (http://creativecommons.org/licenses/by/3.0/). 